\title{
Public-Private Partnership as a Financial Instrument for the Transport Infrastructure Modernizing
}

\author{
Ivan Makarov ${ }^{1}$, and Vladimir Plotnikov ${ }^{2, *}$ \\ ${ }^{1}$ Financial University (Lipetsk branch), 12 Internacionalnaya str., Lipetsk, Russia, 398050 \\ ${ }^{2}$ Saint-Petersburg State University of Economics, 21 Sadovaya str., St. Petersburg, Russia, 191023
}

\begin{abstract}
In the modern economy, there are problems associated with investing in infrastructure development. Its facilities are public goods. Therefore, private business is not interested in their creation and development. And the state does not have sufficient resources to solve the problems of infrastructure development. Therefore, the mechanism of interaction between the state and business on the basis of public-private partnership (PPP) has spread in this sphere. The analysis shows that the forms of PPP depend on the country (region) and industry. Therefore, increasing the effectiveness of PPP, as the authors have shown, should be based on the specificity of projects. The article analyzes the experience and perspectives of PPP development in the Russian transport industry. The authors concluded that the interaction of power and private capital is the most effective mechanism in modern conditions for the creation and development of transport infrastructure in Russia. At the same time, the article focuses on the financial component of PPP in transport.
\end{abstract}

\section{Introduction}

Public-private partnership (PPP) in modern conditions is one of the effective tools for attracting private and public investment in large infrastructure projects [1, 2, 3, 4, etc.]. This form of interaction between the state and business makes it possible to balance risks, as well as optimize the costs of both the state and business. In this regard, this topic is at the centre of attention of many researchers, including authors $[5,6$, etc.].

PPP projects have become very widespread in various countries around the world. At the same time, despite the commonness of theoretical and methodological approaches, these projects have their own specifics. Basically, it is determined by the country (region) of the project and its industry affiliation.

Country specificity is determined by differences in the institutional environment. In different countries and regions, there are various systems of legislation (formal institutions), as well as historically established rules of business conduct (informal institutions). This has an impact on the choice of the model for the implementation and financing of PPP projects.

\footnotetext{
*Corresponding author: plotnikov_2000@mail.ru
} 
Industry specificity is also of great importance. In industries, the level of risks, the capital intensity of projects, the time of their payback, the level of organizational and technological complexity and other parameters are different. They should be taken into account when developing a model for the implementation and financing of a specific PPP project.

The purpose of the study, the results of which are set forth in the article, is to consider the specifics of the implementation and financing of PPP projects implemented in transport, using the example of the Russian economy.

\section{Financial mechanism and its role in PPP}

In the morphological analysis [7] of finance as a complex system, taking into account the specifics of public-private partnership, it should be noted that the common elements in the definitions of finance and public-private partnership are:

- Presence of redistributive relations of monetary resources and risks of partners;

- Regulating the actions of partners, both in terms of redistributive relations, and in the production of socially significant goods and services (guarded goods);

- Functioning with the aim of creating accessibility (financing) for the population and economic entities of tutored benefits, the generation of which traditionally belongs to the functions of the state.

PPP, according to the authors, can be seen as a phenomenon located at the intersection of project finance, financial management, investment management and state and corporate finance. This position of authors is determined by the following arguments:

Firstly, public-private partnership is a mechanism for financial interaction between the state and corporate finance in market conditions;

Secondly, PPP is a mechanism for financing the production of those goods (services) that are produced in developed countries, mainly by state structures. This function can be delegated to private PPP partners due to the desire to ease the burden on the budget system or the lack of budgetary funds;

Thirdly, public-private partnership can be attributed to the sphere of financial management, based on its understanding, as a specific area of management related to the purposeful organization of cash flows, the formation of capital, money incomes and funds needed to achieve strategic development goals [8].

Naturally, like any complex multidimensional socio-economic phenomenon, publicprivate partnership can not be reduced solely to the financial sphere. But the financial component of PPP is very significant. Therefore, in our study, the main focus is on the financial aspects of PPPs.

We consider it necessary to draw on the principles and methodology of resource and institutional approaches, as well as the principle of harmonizing public and private interests, when considering the nature and characteristics of public-private partnership as a mechanism for financial interaction between the state and corporate finance. This view is based on the assessment of the functional purpose of public-private partnerships - the production of guarded goods, the financial provision of this production. In particular, we are talking about state guarantees for provision of infrastructure services to households and businesses.

PPP is considered as a financial investment project. This is a system of project type. PPP has clear goals of creation, principles, forms of existence and the mechanism of interaction of links in the course of the project. The objectives of the investment project, which include the goals and principles for the formation and financing of each specific PPP investment project, should take into account the institutional environment of the 
implementation region. On this basis, specific forms and functions of the PPP project are created.

The target setting of the public-private partnership project is, in our case, the set of goals and objectives set in the formation of each specific partnership. They must be expressed in quantitatively measurable parameters (for example, the length of the constructed railway track, the increase in the number of the motorway, the growth of the road capacity, etc.). These parameters may have an indirect character (for example, the coverage ratio of the road network of settlements, the connectivity of the road network, the number of kilometers of railways per square kilometer of the territory, etc.).

Important for modern Russia is the implementation of PPP projects in transport. Examples of successfully implemented projects include the construction of the Western High-Speed Diameter (St. Petersburg), the reconstruction of the Pulkovo Airport, the construction of the Odintsovo bypass on the federal M-1 highway, etc. According to existing estimates, the total investment in PPP projects in the transport sector exceeds 1 trillion rubles, these projects in Russia account for about $70 \%$ of the total market volume in monetary terms. In this regard, it is required to identify the specifics of financing PPP projects in transport.

\section{The historical aspect of interaction between the state and transport business in Russia (on the example of railways)}

The starting point for the appearance in Russia of railway companies operating on the principles of public-private partnership can be considered April 15, 1836. On this date was signed the decree of Emperor Nicholas I on the construction of the railway Petersburg Tsarskoe Selo. At the initial stage of development of railways in this industry the state dominated. In the period 1837-1856 railway construction was carried out by state enterprises and financed by the treasury.

The situation changed significantly with the coming to power of Emperor Alexander II (the years of the rule of 1855-1881). In the Russian Empire, the active interaction of the state with private capital begins. To finance the construction and operation of railway lines, new business structures are being created in the form of joint-stock companies. They built about $88 \%$ of the length of the railway network. The industry is actively involved in private entrepreneurs.

In total, in the Russian Empire in the period 1836-1916 at the expense of equity capital, $67.5 \%$ of the railway lines were built, and at the expense of the state treasury $-28.5 \%$ of the lines [9].

The largest joint-stock company was the "Main Company of Russian Railways". It united the private capitals of Russia (37.5\% of shares) and a number of European countries (France, England and Germany - $62.5 \%$ of shares) [9]. This company was given a monopoly on the right to build the main roads. Other joint-stock companies and private entrepreneurs were initially allowed to build only secondary railways. In addition, part of the railway network, previously built on treasury funds, was transferred to private hands. Thus, by 1871 the vast majority of the railways of Russia were privately owned.

Let's analyze the features of the scheme of interaction between the state and business in the construction and operation of railways during this period:

1. Granting significant privileges to the "Main Company" significantly slowed the development of the railway network and caused a significant outflow of capital. Instead of building roads, its founders were carried away by financial speculation.

2. The practice of attracting private capital in small joint-stock companies and private entrepreneurs to the construction of railway lines without holding competitive tenders was positive. This allowed to significantly accelerate the pace of railway construction. 
3. There was an inconsistency in the economic interests of the state, society and owners of private companies. The construction of a number of private railways was carried out by entrepreneurs without taking into account the economic interests of the society: the constructed roads did not meet the required level of throughput and carrying capacity, which affected their financial results.

4. There was no state strategic planning. The usual practice was to issue concessions for the construction of short lines. The length of the railway lines built before 1881 was on average 200-250 kilometers [9]. On the other hand, the construction of short lines made it possible to build them in a rather short time.

5. The organization of operational activities of railroads owned by small companies was inefficient. This was determined by the inability to use the positive economies of scale, lack of own resources, inconsistency in management decisions of various companies. As a result, it was impossible to take advantage of a unified rail network.

The natural outcome of these circumstances was:

1. Significant number of bankruptcies of private railway companies; need for their state support from the budget. For example, in 1881, out of 47 railway companies, only 6 were dispensed with without state financial assistance [10].

2. Reduce the pace of construction and commissioning of new lines. This trend has been clearly traced since 1874 .

3. Development of integration processes in the environment of private companies. The primary form of this integration was mergers and acquisitions.

This situation was typical not only for the Russian Empire, but also for other countries. For example, in the US, railway companies also actively integrated for reasons similar to those in Russia. The rail transport industry, therefore, has traveled from small enterprises operating on two finite lengths of fifty-mile routes, to the economic systems operating on multi-hundred-mile highways and, eventually, several hundred thousand miles [11].

The consolidation of business and concentration of capital took place not only on the initiative of private companies, but also the state. In Russia, the active activity of the state in buying out private roads became a distinctive feature. From 1881 to 1900 the treasury purchased 37 private roads with a total length of 21 thousand versts [10]. Such activities were caused by the need to create more economically the infrastructure of social and economic development. The government found it more profitable to buy private railways than to allocate loans to repay loans and pay guaranteed dividends on shares of private railway companies.

The question of the best form of ownership and attraction of capital in the formation of the country's railway network was considered by the outstanding Russian minister-reformer $\mathrm{S}$. Yu. Witte. He pointed out that in the railway industry there are a lot of contradictory economic interests. Because of the conflict, leaving the roads run by private entrepreneurs is risky. Their decisions can damage the interests of society. He argued that the management of railways directly by the government is the form most satisfying the roads of their destination [12].

As a result of large-scale financing of railways, an impetus was given to the development of the entire economy of the Russian Empire. The development of rail transport has contributed to the specialization of the regions, increased mobility of the population, the development of domestic and foreign markets, etc. The development of rail transport had a significant effect on the development of industry. And at the same time the most active role was played by joint-stock (private) capital.

Based on the analysis of the historical experience of the development of Russian railways using various forms of PPP and public financing, it is possible to draw conclusions: 
1. It is necessary to exclude the possibility of fraud, exchange speculation and extortion of money by business from the state for the implementation of projects when developing projects planned for implementation on the basis of a public-private partnership. Instruments such as open auctions, performance auditing and a limited right of recourse should be used.

2. It is necessary to exclude the situation when one company gets an opportunity to build lines of great economic importance, in fact monopolizing the market of infrastructure PPP projects, and other initiatives are proposed to compete for the construction of "minor" lines.

3. The development of infrastructure networks requires a single strategic state plan. At the technical level of planning and coordination, the use of uniform standards is mandatory.

This experience is recommended by the authors for use in modern conditions.

\section{Prospects for the development of PPP in transport}

Considering the prospects for the development of the railway transport system in Russia using PPP, special attention should be paid to the development and implementation of new infrastructure projects. Based on the existence of significant differences in the business environment in the European and Asian parts of the country, the strategy for the development of network infrastructure in these parts of the country must be based on different assumptions.

In the European part of Russia, it is most likely that the main source of revenue from the construction and operation of the network will be operating activities. This implies a high level of risks associated with the possibility of insufficient level of payback for the project level of cargo flow.

In the Asian part of Russia, the construction of new lines involving private capital seems more likely and promising. The basis for such conclusions is the presence of significant reserves of natural resources in the eastern part of the country. Accordingly, subject to the parallel implementation of projects for the development of the extractive and processing industry, first of all, the development of resources of the adjacent territories, the overall financial and social effect will be much larger than in the European part of the country, and there will also be a lesser threat to the financial effect of the project.

The author's calculations (carried out by Ivan Makarov) showed that if we send $10 \%$ of the cost of potentially useful mineral deposits to the construction of a railway network in the Asian part of Russia, then, according to a pessimistic estimate, financial resources will be enough for the construction of railway lines with a length of about 30 thousand kilometers. This is comparable to the current total length of the railway network in the Asian part of Russia.

The choice of a concrete form of partnerships should be decided individually in each case. Taking into account the experience of China, the authors recommend the construction of new cargo lines of short length. For this, a concession mechanism can be used. Reconstructed lines or lines, in which passenger transportation is supposed to be carried out in parallel with carrying out freight work, is proposed to be transferred to joint ownership. This will allow the state to exert an operative influence on the process of managing the activities of transport companies.

The intensity of the state's participation in partnership with private capital must be dependent on the level of public demand for the transported goods produced by transport enterprises. To meet this condition, the development of PPP projects for the development of the region's railway transport system should be based on the strategy (program) of the socio-economic development of the region concerned. 
The need for PPP development in the Russian transport system is conditioned by the fact that private capital is unable to independently develop and implement a set of such large-scale activities as the modernization and development of an infrastructure network with the provision of conditions for the social and economic development of regions. The need to involve the private sector, in turn, is due to the inadequate resources of the state for the implementation of the entire national infrastructure modernization program.

Sources of financing of the system of public-private partnership in the transport sector in the medium term will be the revenues from freight transportation. In the long term, in accordance with the concept of project financing and the principle of applying a limited right of recourse, the main sources of funding for the partnership should be cash flows from (1) carrying out transport activities and (2) developing the resource potential of new economic development areas.

\section{Conclusion}

Transport is a critical element of the national infrastructure. From its development depends not only economic activity, but also the quality of life of the population, its social wellbeing. In this regard, the development of transport infrastructure is one of the important strategic tasks in the modern conditions. This task is especially acute for Russia, the largest country in the world in terms of area.

The historical experience and experience of various countries of the world, which modernize the economy, shows that large-scale development of transport by the forces of only private business or only the state has little chance of success. This is due to the need for sectoral coordination, significant resource costs, the combination of public and private economic interests, the risks of implementing large and capital-intensive projects.

PPP is an effective form of interaction between the state and business in the creation and operation of transport infrastructure. It is necessary to develop and institutionalize models of interaction (including financial models) in this area. One of the prerequisites for this is the development of legislation at the regional level.

\section{References}

1. I. A. Freidina. International Experience of Infrastructure Projects Financing. Ekonomicheskaya politika, 12 (4) (2017).

2. D. A. Macheret, I. A. Epishkin. Mutual influence of institutional and transport factors of economic development: retrospective analysis. Journal of institutional studies, 9 (4) (2017).

3. A. Obraztsova, L. Kamenik. Organization of public private partnership in the renovation of urban areas. MATEC Web of Conferences, 106 (2017).

4. M. Shibayeva, Y. Serebryakova, O. Shalnev. Efficiency improvement of the investment and innovation activities in the transport facility construction field with public-private partnership involvement. IOP Conference Series-Earth and Environmental Science, 90 (2017).

5. I. N. Makarov. Structural reforms and perspectives of the state-private partnership in the natural and monopoly sector of the economy of Russia. Voronezh (2007).

6. J. Vertakova, V. Plotnikov. Russian and foreign experience of interaction between government and business. World Applied Sciences Journal, 28 (3) (2013). 
7. Y. Vertakova, M. Klevtsova, T. Babich. Identification of the new research areas and development of the existing ones by methods of morphological analysis and synthesis. Economic Annals-XXI, 157 (3-4) (2016).

8. M. V. Romanovsky, O. V. Vrublevskaya (eds.). Finance, money circulation and credit. Moscow, Yurait Publishing (2006).

9. Yu. B. Vinslav, G. V. Kotov. Reforming the railway complex: the option of creating a multi-level state holding. Russian economic journal, 3 (2001).

10. N. E. Aksenenko, B. M. Lapidus, A. S. Misharin. Russia's Railways: From Reform to Reform. Moscow, Transport Publishing (2001).

11. O. E. Williamson. The economic institutions of capitalism: Firms, Markets, Relational Contracting. London, Collier Macmillan Publishers (1985).

12. S. Yu. Witte. Abstract lectures on the national and state economy, read to his Imperial Highness Grand Duke Mikhail Alexandrovich in 1900-1902. Moscow, Nachala Publishing (1997). 